\title{
1,25(OH) $)_{2}$ Vitamin $D_{3}$ Stimulates Membrane Phosphoinositide Turnover, Activates Protein Kinase C, and Increases Cytosolic Calcium in Rat Colonic Epithelium
}

Ramesh K. Wali, Charles L. Baum, Michael D. Sitrin, and Thomas A. Brasitus

Department of Medicine, University of Chicago, Chicago, Illinois 60637

\begin{abstract}
The hormonal form of vitamin $\mathrm{D}, 1,25(\mathrm{OH})_{2}$ vitamin $\mathrm{D}_{3}$ $\left[1,25(\mathrm{OH})_{2} \mathrm{D}_{3}\right]$, regulates colonic calcium absorption and colonocyte proliferation and differentiation. In this study, we have examined the effect of $1,25(\mathrm{OH})_{2} \mathrm{D}_{3}$ on membrane phosphoinositide turnover, protein kinase $\mathrm{C}$ activation, and regulation of intracellular calcium concentration $\left(\left[\mathrm{Ca}^{+2}\right]_{i}\right)$ in isolated rat colonic epithelium. In a concentration-dependent manner, $1,25(\mathrm{OH})_{2} \mathrm{D}_{3}$ stimulated breakdown of membrane phosphoinositides within $15 \mathrm{~s}$, generating diacylglycerol and inositol 1,4,5-triphosphate $\left(\mathrm{IP}_{3}\right)$. 1,25(OH $)_{2} \mathrm{D}_{3}$ rapidly activated colonic protein kinase $\mathrm{C}$, with maximal translocation of activity from the cytosol to the membrane occurring within $1 \mathrm{~min}$ of exposure to the secosteroid. Studies performed in isolated colonocytes with the fluorescent dye fura- 2 demonstrated that $10^{-8} \mathrm{M} 1,25(\mathrm{OH})_{2} \mathrm{D}_{3}$ caused a rapid rise in $\left[\mathrm{Ca}^{+2}\right]_{i}$ which then transiently decreased before rising to a new plateau value. When these experiments were performed in a calcium-free buffer, an increase in $\left[\mathrm{Ca}^{+2}\right]_{i}$ was observed, but both the transient and secondary rise were diminished in magnitude, suggesting that $1,25(\mathrm{OH})_{2} \mathrm{D}_{3}$ may stimulate both release of intracellular calcium stores and calcium influx. 1,25(OH $)_{2} \mathrm{D}_{3}$ stimulated $\left[{ }^{3} \mathrm{H}\right]$ thymidine uptake in rat colonocytes, $4 \mathrm{~h}$ after an in vivo injection. These studies indicate that $1,25(\mathrm{OH})_{2} \mathrm{D}_{3}$ exerts a rapid influence on membrane phosphoinositide metabolism which may mediate certain of the secosteroid's effects on colonocyte calcium transport and proliferation. (J. Clin. Invest. 1990. 85:1296-1303.) 1,25(OH $)_{2}$ vitamin $D_{3} \cdot$ phosphoinositide metabolism - intracellular calcium $\bullet$ protein kinase $\mathrm{C}$. diacylglycerol
\end{abstract}

\section{Introduction}

The hormonally active form of vitamin $\mathrm{D}, 1,25(\mathrm{OH})_{2}$ vitamin $\mathrm{D}_{3}\left[1,25(\mathrm{OH})_{2} \mathrm{D}_{3}\right],{ }^{1}$ has a well-recognized role in regulating

A preliminary report of this research was presented at the Seventh Workshop on Vitamin D, 25-29 April 1988, Rancho Mirage, CA (Norman, A. W., H.-G. Grigoleit, and D. V. Herrth, editors. 1988. Molecular and Cellular Clinical Endocrinology. Walter de Gruyter, Berlin, 429-430).

Received for publication 6 March 1989 and in revised form 30 October 1989.

1. Abbreviations used in this paper: $\mathrm{IP}, \mathrm{IP}_{2}$, and $\mathrm{IP}_{3}$, inositol-1-monophosphate, inositol-1,4-bisphosphate, and inositol-1,4,5-triphosphate; KRBG, KRB containing $180 \mathrm{mg} \%$ glucose; PI, PIP, and PIPP, phosphatidylinositol, phosphatidylinositol-4-phosphate, and phosphatidylinositol-4,5-bisphosphate.

J. Clin. Invest.

(c) The American Society for Clinical Investigation, Inc.

0021-9738/90/04/1296/08 $\$ 2.00$

Volume 85, April 1990, 1296-1303 calcium absorption and mineral metabolism (1). More recently, it has been established that $1,25(\mathrm{OH})_{2} \mathrm{D}_{3}$ has potent influences on cell proliferation and differentiation in many tissues $(2,3)$. In several malignant cell lines, including some derived from colon carcinomas, $1,25(\mathrm{OH})_{2} \mathrm{D}_{3}$ has been shown to stimulate differentiation while inhibiting proliferation $(4$, $5)$. The effect of $1,25(\mathrm{OH})_{2} \mathrm{D}_{3}$ on growth in normal tissues has been less extensively studied. Birge and Alpers (6) found that repletion of vitamin D-deficient rats rapidly stimulated intestinal mucosal cell proliferation, which was associated with a $20 \%$ increase in villus cell number by $32 \mathrm{~h}$. The colonic epithelium is of interest since it manifests both the classic and nonclassic actions of vitamin D. Colonic calcium absorption is vitamin D-responsive, and in some circumstances, such as the short bowel syndrome, may be important in calcium homeostasis $(7,8)$. In addition, the effect of $1,25(\mathrm{OH})_{2} \mathrm{D}_{3}$ on colonocyte growth and differentiation is of particular interest in view of epidemiologic evidence suggesting that sunlight exposure and dietary vitamin $\mathrm{D}$ and calcium intake may influence the prevalence of colonic carcinoma $(9,10)$.

Many of the effects of $1,25(\mathrm{OH})_{2} \mathrm{D}_{3}$ on cellular function can clearly be attributed to its action as a steroidlike hormone. High affinity $1,25(\mathrm{OH})_{2} \mathrm{D}_{3}$ receptors are present in many cell types, including the colon, and interaction of the $1,25(\mathrm{OH})_{2} \mathrm{D}_{3}$-receptor complex with chromatin alters gene expression (11). Attention has focused recently, however, on cellular responses to $1,25(\mathrm{OH})_{2} \mathrm{D}_{3}$ that are very rapid (12) and are not blocked by inhibitors of transcription and translation (13). Several workers have suggested a "liponomic" action of $1,25(\mathrm{OH})_{2} \mathrm{D}_{3}$, where the secosteroid exerts direct effects on cell membranes (13-15). Studies in various cell types have indicated that $1,25(\mathrm{OH})_{2} \mathrm{D}_{3}$ alters membrane phospholipid content $(13,14)$, fatty acid composition $(13,15)$, and fluidity $(15)$.

The experiments described in this report demonstrate that $1,25(\mathrm{OH})_{2} \mathrm{D}_{3}$ rapidly stimulates colonic membrane phosphoinositide breakdown, generates inositol 1,4,5-triphosphate $\left(\mathrm{IP}_{3}\right)$ and diacylglycerol, and increases colonocyte intracellular calcium concentration $\left(\left[\mathrm{Ca}^{+2}\right]_{\mathrm{i}}\right)$. As a consequence of the rise in diacylglycerol content and $\left[\mathrm{Ca}^{+2}\right]_{\mathrm{i}}, 1,25(\mathrm{OH})_{2} \mathrm{D}_{3}$ also activates protein kinase $C$, a known regulator of proliferation and differentiation in many cell systems including the colonic epithelium $(16,17)$. Moreover, in vivo injection of $1,25(\mathrm{OH})_{2} \mathrm{D}_{3}$ stimulates $\left[{ }^{3} \mathrm{H}\right]$ thymidine incorporation into the DNA of colonocytes.

\section{Methods}

Materials. $1,25(\mathrm{OH})_{2} \mathrm{D}_{3}$ was kindly provided by Dr. M. R. Uskokovic (Hoffman-LaRoche Inc., Nutley, NJ), and $25(\mathrm{OH}) \mathrm{D}_{3}$ was generously supplied by Dr. J. Babcock (Upjohn Co., Kalamazoo, MI). Leupeptin, phenylmethylsulfonyl fluoride, histone (type III-S), phosphatidylserine, phosphatidylinositol standards, DEAE-cellulose, ATP-Na salt, diethylenetriaminepenta-acetic acid, and morpholine propane sulfonic acid (MOPS) buffer salt were purchased from Sigma Chemical Co. (St. Louis, MO). $\left[1-{ }^{14} \mathrm{C}\right] n$-butyric acid $(15.0 \mathrm{mCi} / \mathrm{mmol}),\left[{ }^{3} \mathrm{H}\right]$ thymidine $(2$ 
$\mathrm{Ci} / \mathrm{mmol}),\left[\gamma{ }^{-32} \mathrm{P}\right] \mathrm{ATP},\left[{ }^{3} \mathrm{H}\right]$ arachidonate, $\left[{ }^{3} \mathrm{H}\right]$ myoinositol, $\left[{ }^{3} \mathrm{H}\right]$ phosphatidylinositol compounds, and $\left[{ }^{3} \mathrm{H}\right]$ inositol phosphate compounds were obtained from New England Nuclear Research Products (Boston, MA). Fura-2 and fura-2 AM (acetoxymethyl ester) were obtained from Molecular Probes (Eugene, OR). Sn-1,2-diacylglycerol kinase was purchased from Lipidex, Inc. (Westfield, NJ), octyl- $\beta$-D-glucoside from Boerhinger Mannheim Biochemicals (Indianapolis, IN), and cardiolipin and dioleoyl glycerol from Avanti Polar Lipids, Inc. (Pelham, AL).

Isolation of intact colonic epithelium. For the studies of phosphatidylinositol metabolism and protein kinase $\mathrm{C}$ activation, an intact rat colonic epithelium preparation was used. The colonic epithelium was isolated as described by Craven et al. (18). Briefly, after anesthesia with pentobarbital $(50 \mathrm{mg} / \mathrm{kg}$ i.p.), the colon was flushed with $20 \mathrm{ml}$ of $\mathrm{Ca} / \mathrm{Mg}$-free Hanks' balanced salt solution at $37^{\circ} \mathrm{C}$. A 16-gauge needle was placed in the left ventricle and perfused for 3-4 min at a flow rate of $20 \mathrm{ml} / \mathrm{min}$ with $30 \mathrm{mM}$ EDTA in $\mathrm{Ca} / \mathrm{Mg}$-free Hanks' solution flushed with $95 \%$ oxygen and $5 \% \mathrm{CO}_{2}$ at $37^{\circ} \mathrm{C}$. The colon was then excised, gently everted on a glass rod and slid over a $1-\mathrm{ml}$ pipette attached to a rheostat-controlled motor. The epithelium was removed by 5 -s bursts of rotation at $1,600 \mathrm{rpm}$ and collected in cold Krebs Ringer bicarbonate buffer, $\mathrm{pH} 7.4$, containing $180 \mathrm{mg} \%$ glucose (KRBG). The epithelium was centrifuged at $500 \mathrm{~g}$, washed, and resuspended in the same buffer. Cell viability was assessed by the ability of the colonic crypts to metabolize $\left[{ }^{14} \mathrm{C}\right] n$-butyrate to ${ }^{14} \mathrm{CO}_{2}$ (19). This reaction was linear for $2 \mathrm{~h}$. In addition, trypan blue exclusion in $>90 \%$ of all cells was observed for at least $2 \mathrm{~h}$.

Treatment of the colonic epithelium with $1,25(\mathrm{OH})_{2} D_{3}$. The colonic epithelium was incubated in $\mathrm{KRBG}$ at $37^{\circ} \mathrm{C}$ for a total of $30 \mathrm{~min}$. The time course of the effect of $1,25(\mathrm{OH})_{2} \mathrm{D}_{3}$ on protein kinase $\mathrm{C}$ was determined by adding the vitamin at different time intervals during the final $15 \mathrm{~min}$ of the incubation. To study the dose-response relationship, different concentrations of $1,25(\mathrm{OH})_{2} \mathrm{D}_{3}\left(10^{-12}\right.$ to $\left.10^{-8} \mathrm{M}\right)$ were incubated with the colonic epithelium for the last minute of incubation. The control epithelial preparations were treated with an appropriate amount of ethanol vehicle, with the final ethanol concentration never exceeding $0.004 \%$.

Partial purification of protein kinase $C$. After incubation with $1,25(\mathrm{OH})_{2} \mathrm{D}_{3}$ or vehicle, $20 \mathrm{ml}$ of ice-cold $\mathrm{KRBG}$ buffer was added to each tube and the contents immediately centrifuged at $500 \mathrm{~g}$ for $5 \mathrm{~min}$. The pellets were then homogenized 15 strokes with a motor-driven teflon pestle in $5 \mathrm{ml}$ of homogenization buffer containing $20 \mathrm{mM}$ Tris- $\mathrm{HCl}, \mathrm{pH} 7.5,0.5 \mathrm{mM}$ EGTA, $2 \mathrm{mM}$ EDTA, $2.0 \mathrm{mM}$ phenylmethylsulfonyl fluoride, $0.5 \mathrm{mM}$ benzimidine, $5.0 \mathrm{mM}$ 2-mercaptoethanol, and $10 \mathrm{mg} /$ liter leupeptin (20). The homogenate was subjected to ultracentrifugation at $100,000 \mathrm{~g}$ for $60 \mathrm{~min}$ and the supernatant $S_{1}$ (cytosolic fraction) saved. The pellet was gently resuspended in $5.0 \mathrm{ml}$ of homogenization buffer containing $0.3 \%$ Triton X-100 (wt/ $\mathrm{wt}$ ) and left on ice for $60 \mathrm{~min}$ before recentrifugation at $100,000 \mathrm{~g}$ for 60 minutes. The supernatant $S_{2}$ (solubilized membrane fraction) was collected and both $S_{1}$ and $S_{2}$ fractions were applied to DEAE-cellulose columns (Poly-prep columns, $0.8 \times 4 \mathrm{~cm}$, Bio-Rad Laboratories, Richmond, CA) that had been preequilibrated in the homogenizing buffer. In preliminary studies, the columns were washed with $16 \mathrm{ml}$ of buffer and eluted with $32 \mathrm{ml}$ of a linear gradient of $0-0.1 \mathrm{M} \mathrm{NaCl}$ in homogenization buffer. As most of the protein kinase $\mathrm{C}$ activity eluted in $0.035-0.055 \mathrm{M} \mathrm{NaCl}$, for routine purposes the loaded columns were first washed with $8 \mathrm{ml}$ of homogenizing buffer and then with $4 \mathrm{ml}$ of the same buffer containing $0.02 \mathrm{M} \mathrm{NaCl}$. Finally, protein kinase $C$ was eluted in $2 \mathrm{ml}$ of buffer containing $0.08 \mathrm{M} \mathrm{NaCl}$. The eluted cytosolic or membrane fractions were assayed for protein kinase $\mathrm{C}$ activity on the same day.

Assay of protein kinase $C$. Protein kinase $\mathrm{C}$ activity was determined using a histone phosphorylation assay, as described previously (20). The DEAE-purified fractions were incubated in a reaction mixture (final volume $75 \mu \mathrm{l}$ ) containing (final concentrations) $20 \mathrm{mM}$ Tris- $\mathrm{HCl}$ (pH 7.2), $10 \mathrm{mM} \mathrm{MgCl}_{2}, 400 \mu \mathrm{g} / \mathrm{ml}$ histone (type III-S), $1.83 \mathrm{mM}$ $\mathrm{CaCl}_{2}$ (the actual concentration of unchelated $\mathrm{CaCl}_{2}$ used was only 1.0 $\mathrm{mM}$, since the contributions of EGTA and EDTA from the column elution buffer were 0.17 and $0.66 \mathrm{mM}$, respectively), and $50 \mu \mathrm{M}[\gamma$ $\left.{ }^{32} \mathrm{P}\right] \mathrm{ATP}(1 \mu \mathrm{Ci})$ with and without $80 \mu \mathrm{g} / \mathrm{ml}$ of phosphatidylserine. Aliquots of phosphatidylserine $(10 \mathrm{mg} / \mathrm{ml}$ ethanol) were evaporated under $\mathrm{N}_{2}$ and sonicated in $20 \mathrm{mM}$ Tris buffer, $\mathrm{pH} 7.4$, before addition to the reaction mixture. Reactions were started by adding $25 \mu \mathrm{l}$ of the protein kinase $\mathrm{C}$ preparation to $50 \mu \mathrm{l}$ of the assay mixture, and the incubations were carried out for $3 \mathrm{~min}$ at $30^{\circ} \mathrm{C} .50 \mu \mathrm{l}$ of the assay mixture was blotted onto $2.5 \times 2.5-\mathrm{cm}$ phosphocellulose papers (No. P81, Whatman Inc., Clifton, NJ) that had been prewashed in $10 \%$ trichloroacetic acid, $2 \mathrm{mM} \mathrm{NaH} \mathrm{PO}_{4}$ solution. The papers were then washed by agitating in $250 \mathrm{ml}$ of ice-cold $10 \%$ TCA for $12 \mathrm{~min}$ and left under running water for $5 \mathrm{~min}$. The filter papers were soaked in $95 \%$ ethanol for $5 \mathrm{~min}$, followed by diethyl ether for an additional $5 \mathrm{~min}$ and then air-dried before taking Cherenkov counts. Protein kinase $C$ activity was calculated from the difference in phosphorylation assayed in the presence and absence of phosphatidylserine. Enzyme activity was linear with respect to enzyme concentration in all assays and activity was expressed as picomoles of ${ }^{32} \mathrm{P}$ per minute per milligram of protein.

Determination of labeled diacylglycerol. The effect of $1,25(\mathrm{OH})_{2} \mathrm{D}_{3}$ on the production of diacylglycerol was determined using colonic epithelial preparations in which membrane phosphoinositides had been prelabeled with $\left[{ }^{3} \mathrm{H}\right]$ arachidonate as previously described (16). Colonic epithelium $(5 \mathrm{mg}$ of protein $/ 5 \mathrm{ml}$ ) was preincubated with $20 \mu \mathrm{Ci}$ of $\left[{ }^{3} \mathrm{H}\right]$ arachidonate for $1 \mathrm{~h}$ at $37^{\circ} \mathrm{C}$. In preliminary experiments, we found that the phosphoinositides were the major phospholipid class labeled with $\left[{ }^{3} \mathrm{H}\right]$ arachidonate $\left(67 \%\left[{ }^{3} \mathrm{H}\right]\right.$ phosphoinositides, $16 \%\left[{ }^{3} \mathrm{H}\right]-$ phosphatidylcholine, $11 \%\left[{ }^{3} \mathrm{H}\right]$ phosphatidylethanolamine, and $6 \%$ $\left[{ }^{3} \mathrm{H}\right]$ phosphatidylserine). The epithelium was washed in KRBG containing $10 \mathrm{mg} / \mathrm{ml}$ fatty acid free albumin, resuspended in KRBG and incubated at $37^{\circ} \mathrm{C}$ for $15 \mathrm{~min}$. During this incubation, $1,25(\mathrm{OH})_{2} \mathrm{D}_{3}$ was added for different time intervals as described above. The reaction was terminated by the rapid addition of ice-cold KRBG, and the crypts were centrifuged at $500 \mathrm{~g}$ at $4^{\circ} \mathrm{C}$ for $10 \mathrm{~min}$. The pellet was extracted in chloroform/methanol 2:1 ( vol/vol), and the lipid extract was then loaded on to a silicic acid column. Neutral lipids were eluted with chloroform (21), and immediately dried under $\mathrm{N}_{2}$ to prevent isomerization of 1,2-diglyceride to 1,3-diglyceride. The neutral lipid samples were spotted onto silica gel $\mathrm{G}$ coated thin-layer chromatography plates and developed with hexane/ethyl ether/acetic acid 80:20:2 (vol/vol/ vol). The lipids were identified with iodine vapor and the spots corresponding to authentic diacylglycerol standard were scraped from the plate, transferred to scintillation vials, and counted.

Measurement of 1,2-diacylglycerol mass. Cell pellets were combined with $10 \mathrm{ml}$ of $2: 1(\mathrm{vol} / \mathrm{vol})$ chloroform/methanol and total cellular lipids extracted as described by Folch et al. (22). An aliquot of this extract was assayed in triplicate for total lipid phosphorus as described by Bartlett (23). Same-day aliquots of lipid extract were also assayed for 1,2-diacylglycerol mass by the diacylglycerol kinase procedure of Preiss et al. (24) with the following modifications. MOPS buffer, $\mathrm{pH}$ 6.6, was substituted for imidizole buffer, $\mathrm{pH} 6.6$ (25). For each reaction tube, diacylglycerol kinase $(20 \mathrm{mU}$ in $10 \mu \mathrm{l})$ was combined with $50 \mu \mathrm{l}$ of reaction buffer (100 $\mathrm{mM}$ Na-morpholine propane sulfonic acid, $\mathrm{pH}$ $6.6,100 \mathrm{mM} \mathrm{NaCl}, 25 \mathrm{mM} \mathrm{MgCl}_{2}, 2 \mathrm{mM}$ EGTA) plus $10 \mu \mathrm{l}$ of $20 \mathrm{mM}$ dithiothreitol and $10 \mu \mathrm{l}$ of $10 \mathrm{mM}\left[\gamma^{32} \mathrm{P}\right] \mathrm{ATP}\left(5.0 \times 10^{4} \mathrm{cpm} / \mathrm{nmol}\right)$, and the mixture was incubated at $25^{\circ} \mathrm{C}$ for $30 \mathrm{~min}$. as described by Wright et al. (26). Duplicate aliquots of dioleoylglycerol standards or cellular lipid extracts were transferred to $75 \times 12-\mathrm{mm}$ capped polyethylene tubes (Sarstedt, Inc., Princeton, NJ) and dried under argon. A $20-\mu$ l aliquot of resuspension buffer (7.5\% octyl- $\beta$-D-glucoside, $5 \mathrm{mM}$ cardiolipin, $1 \mathrm{mM}$ diethylenetriamine penta-acetic acid) was added, vortexed, and sonicated as described (24). To this, $80 \mu \mathrm{l}$ of the enzyme-ATP mixture was added, followed by vortex mixing and incubation at $25^{\circ} \mathrm{C}$ for $30 \mathrm{~min}$. The reaction was terminated by the addition of $1.67 \mathrm{ml}$ of $\mathrm{CHCl}_{3} / \mathrm{MeOH} / 12 \mathrm{~N} \mathrm{HCl}(66: 31: 1$, vol/vol/vol), followed by $1.67 \mathrm{ml}$ of $\mathrm{MeOH} / \mathrm{H}_{2} \mathrm{O} / \mathrm{CHCl}_{3}(48: 47: 3$, vol/vol/vol) as described by MacDonald et al. (25), followed by vortex mixing and centrifugation. The upper phase was removed and discarded, and the 
lower phase was reextracted with $1.67 \mathrm{ml}$ of $\mathrm{MeOH} / \mathrm{H}_{2} \mathrm{O} / \mathrm{CHCl}_{3}$ (48:47:3, vol/vol/vol). After centrifugation and removal of the upper phase, the labeled phosphatidic acid in the lower phase was assayed directly by scintillation counting of an aliquot as justified by Muldoon et al. (27). Standard curves were generated from the assay of known amounts of 1,2-diacylglycerol and data expressed as nanomoles of 1,2 diacylglycerol/100 $\mathrm{nmol}$ of lipid phosphorous ( $\mathrm{mol} \%)(26)$.

Determination of labeled inositol phosphates and phosphoinositides. The effect of $1,25(\mathrm{OH})_{2} \mathrm{D}_{3}$ on the colonic content of inositol phosphates and membrane phosphoinositides was determined using colonic epithelial preparations prelabeled with $\left[{ }^{3} \mathrm{H}\right]$ myoinositol. Colonic epithelium (10 mg protein) was incubated for $2 \mathrm{~h}$ in $2 \mathrm{ml}$ of KRBG containing $25 \mu \mathrm{Ci}$ of $\left[{ }^{3} \mathrm{H}\right]$ myoinositol (sp act $12.8 \mathrm{Ci} / \mathrm{mmol}$ ). In preliminary experiments, we found that $0.21 \%$ of $\left[{ }^{3} \mathrm{H}\right]$ myoinositol was incorporated into the phosphoinositol fraction of total cellular lipid. The epithelium was centrifuged at $500 \mathrm{~g}$ for $10 \mathrm{~min}$ at $4^{\circ} \mathrm{C}$ and washed three times with cold KRBG. The crypts were then resuspended in 2 $\mathrm{ml}$ of $20 \mathrm{mM}$ Hepes/Tris buffer, $\mathrm{pH} 7.0$, containing $25 \mathrm{mM} \beta$-glycerophosphate, $2.0 \mathrm{mM}$ EGTA/ $\mathrm{Ca}^{+}, 0.1 \mathrm{M} \mathrm{KCl}, 5 \mathrm{mM} \beta$-mercaptoethanol, $5 \mathrm{mM} \mathrm{MgCl} 2,0.02 \%$ trypsin inhibitor, and $10 \mathrm{mM} \mathrm{LiCl}$. Use of this buffer was associated with the most reliable results and is similar to other buffers used for the assay of inositol phosphates and phosphoinositides. The suspensions were incubated for $15 \mathrm{~min}$ at $37^{\circ} \mathrm{C}$ and $1,25(\mathrm{OH})_{2} \mathrm{D}_{3}$ was added as above. The reactions were terminated by addition of $0.67 \mathrm{ml} 10 \%$ perchloric acid and allowed to stand on ice for $15 \mathrm{~min}$. After centrifugation at $500 \mathrm{~g}$, the supernatant was neutralized with $20 \mathrm{mM}$ Hepes/Tris buffer, $\mathrm{pH} 8.0$, before determination of inositol phosphates. The pellet was mixed with $0.5 \mathrm{ml}$ chloroform/metha$\mathrm{nol} / 12 \mathrm{~N} \mathrm{HCl}(200: 100: 0.75, \mathrm{vol} / \mathrm{vol} / \mathrm{vol})$ and the extracted phosphoinositides were saved for later analyses. Separation of different species of inositol phosphates was achieved by anion-exchange chromatography on $0.3 \mathrm{ml} \mathrm{AG-I} \times 8\left(\mathrm{HCOO}^{-}\right)$columns $(200-400$ mesh) based on the method of Downes et al. (28). After loading, the columns were eluted serially with $1.5 \mathrm{ml}$ each of $(a)$ water, $(b) 0.1 \mathrm{M}$ formic acid, $0.2 \mathrm{M}$ ammonium formate, (c) $0.1 \mathrm{M}$ formic acid, $0.4 \mathrm{M}$ ammonium formate, and $(d) 0.1 \mathrm{M}$ formic acid, $1 \mathrm{M}$ ammonium formate. Inositol-1-monophosphate (IP), inositol-1,4-bisphosphate $\left(\mathrm{IP}_{2}\right)$ and $\mathrm{IP}_{3}$ eluted in the second, third, and fourth fractions, respectively. The samples were mixed with scintillation fluid and counted. For the separation and quantification of phosphoinositides, $0.2 \mathrm{ml}$ of the acidified pellet extract was treated with $1.5 \mathrm{ml}$ of chloroform/methanol $(2: 1$ $\mathrm{vol} / \mathrm{vol})$, vortexed, and centrifuged. The upper phase was discarded and the lower phase was washed two times with $0.75 \mathrm{ml}$ methanol $/ 0.6$ $\mathrm{N} \mathrm{HCl}(1: 1, \mathrm{vol} / \mathrm{vol})$ and then separated on $1 \% \mathrm{~K}$-oxalate impregnated silica gel $\mathrm{G}$ chromatography plates. Unlabeled phosphoinositides were added as carriers. The plates were developed in chloroform/acetone/ methanol/glacial acetic acid/ $\mathrm{H}_{2} \mathrm{O}(40: 15: 13: 12: 7 \mathrm{vol} / \mathrm{vol} / \mathrm{vol} / \mathrm{vol} / \mathrm{vol})$ (29). The labeled phosphoinositides including phosphatidylinositol (PI), phosphatidylinositol-4-phosphate (PIP), and phosphatidylinositol-4,5-bisphosphate (PIPP) were visualized by spraying the plates with En ${ }^{3}$ hance (New England Nuclear) and exposing to X-ray film (SM-5) (Eastman Kodak Co., Rochester, NY), using a Kodak X-OMAT enhancing screen, for 3-5 d. Individual phosphoinositide spots were identified by comparison with authentic standards, and quantified by scraping the silica gel from the plate and counting the radioactivity in a liquid scintillation counter.

Isolation of colonocytes. Colonic epithelial cells were isolated as described previously (30). The colon was removed, tied at one end, and rinsed in $0.9 \% \mathrm{NaCl}$ containing $1.0 \mathrm{mM}$ dithiothreitol. The colon was then filled with $0.1 \mathrm{M}$ phosphate-buffered saline, $\mathrm{pH} 7.2$, containing $1.5 \mathrm{mM}$ EDTA and $0.5 \mathrm{mM}$ dithiothreitol and closed with a Dieffenbach Serrefine clamp (Millers Forge, Plano, TX). The colonic sacs were incubated in $150 \mathrm{ml}$ of phosphate-buffered saline at $37^{\circ} \mathrm{C}$ for 30 min. Sacs were emptied and cells were collected by centrifugation at $500 \mathrm{~g}$, rinsed in phosphate-buffered saline, and resuspended in the appropriate buffer for measurement of intracellular calcium concentration. Cells were routinely viable for at least $1 \mathrm{~h}$ as assessed by trypan blue exclusion.
Measurement of intracellular calcium concentration $\left(\left[\mathrm{Ca}^{+2}\right]_{i}\right)$. Isolated colonocytes were incubated with $1 \mu \mathrm{M}$ fura- $2 \mathrm{AM}$ for $30 \mathrm{~min}$ at $37^{\circ} \mathrm{C}$. The cells were collected by centrifugation at $500 \mathrm{~g}$ for $5 \mathrm{~min}$ at $4^{\circ} \mathrm{C}$, and resuspended in buffer containing $145 \mathrm{mM} \mathrm{NaCl}, 5 \mathrm{mM} \mathrm{KCl}$, $10 \mathrm{mM}$ Hepes, $5 \mathrm{mM} \mathrm{MgCl}$, $10 \mathrm{mM}$ D-glucose, pH 7.2 (31). Studies were performed using buffers containing $1 \mathrm{mM} \mathrm{CaCl}_{2}$, or calcium-free with and without $1 \mathrm{mM}$ EGTA. The kinetics of fluorescence changes in the fura-2-loaded colonocytes were analyzed using an SLM-4800 C spectrofluorometer (SLM Instrument, Inc., Urbana, IL). The cuvette containing the colonocytes was constantly stirred and maintained at $37^{\circ} \mathrm{C} .1,25(\mathrm{OH})_{2} \mathrm{D}_{3}$ or vehicle was injected directly into the cuvette. Fluorescence was measured at excitation wavelengths of 340 and 380 $\mathrm{nm}$, with emission at $505 \mathrm{~nm}$. Signals from the fluorometer were fed into an IBM-PC (IBM Instruments, Inc., Danbury, CT) with SLM spectrum processor version 3.2 for subsequent analysis. $\left[\mathrm{Ca}^{+2}\right]_{\mathrm{i}}$ was calculated based on the formula of Grynkyewicz et al. (32) assuming the $K_{\mathrm{d}}$ of the $\mathrm{Ca}^{+2}$-fura-2 interaction to be $225 \mathrm{nM}$ in the cytosolic environment. The calibration of $\left[\mathrm{Ca}^{+2}\right]_{i}$ was based on spectra of $1 \mu \mathrm{M}$ fura-2 (penta potassium salt) in $\mathrm{Ca}^{+2}$-EGTA buffers with free $\mathrm{Ca}^{+2}$ values ranging from $<1$ to $>10 \mu \mathrm{M}$.

$\left[{ }^{3} \mathrm{H}\right]$ Thymidine incorporation in rat colonocytes. Rats weighing $250-300 \mathrm{~g}$ were injected subcutaneously with either $1,25(\mathrm{OH})_{2} \mathrm{D}_{3}(10$ $\mathrm{ng} / 100 \mathrm{~g}$ body weight) or ethanol vehicle. After $2 \mathrm{~h}$ the rats were injected intraperitioneally with $100 \mu \mathrm{Ci}$ of $\left[{ }^{3} \mathrm{H}\right]$ thymidine. $4 \mathrm{~h}$ after $1,25(\mathrm{OH})_{2} \mathrm{D}_{3}$ injection the rats were killed and colonocytes prepared as described above. $\left[{ }^{3} \mathrm{H}\right]$ Thymidine incorporation was measured according to Verbin and Farber (33). DNA was extracted from the precipitate with $10 \% \mathrm{TCA}$ at $90^{\circ} \mathrm{C}$ for $10 \mathrm{~min}$ and measured as previously described (34).

Statistical analysis. Data were analyzed using Student's $t$ test for unpaired data (35).

\section{Results}

Effect of $1,25(\mathrm{OH})_{2} D_{3}$ on colonic phosphoinositides and inositol phosphates. To examine the effect of $1,25(\mathrm{OH})_{2} \mathrm{D}_{3}$ on phosphatidylinositol metabolism, studies were performed using colonic epithelium that was prelabeled with $\left.{ }^{3} \mathrm{H}\right]$ myoinositol. As shown in Table I, administration of $10^{-8} \mathrm{M}$ $1,25(\mathrm{OH})_{2} \mathrm{D}_{3}$ caused a decrease in the membrane content of labeled phosphoinositides within $15 \mathrm{~s}$, with the most prominent response seen in the labeled PIPP content. Concomitantly, there was an increase in the colonic levels of inositol phosphates, with the greatest change seen in the $\mathrm{IP}_{3}$ content which increased more than twofold at $30 \mathrm{~s}$ and $1 \mathrm{~min}$. As indicated in Table II, the effect of $1,25(\mathrm{OH})_{2} \mathrm{D}_{3}$ on phosphoinositide bisphosphate breakdown and $\mathrm{IP}_{3}$ formation was dose-dependent, with $10^{-8} \mathrm{M} 1,25(\mathrm{OH})_{2} \mathrm{D}_{3}$ producing a greater effect than $10^{-10} \mathrm{M}$.

Effect of $1,25(\mathrm{OH})_{2} \mathrm{D}_{3}$ on colonic diacylglycerol. Colonic epithelium was prelabeled with $\left[{ }^{3} \mathrm{H}\right]$ arachidonate as shown in Fig. 1. Treatment with $1,25(\mathrm{OH})_{2} \mathrm{D}_{3}$ rapidly increased the colonic $\left[{ }^{3} \mathrm{H}\right]$ diacylglycerol content, with a maximum response seen at $15-30 \mathrm{~s}$. At later time points, the $\left[{ }^{3} \mathrm{H}\right]$ diacylglycerol content decreased towards the baseline value. The effect of $1,25(\mathrm{OH})_{2} \mathrm{D}_{3}$ on diacylglycerol levels was concentration-dependent (Fig. 2), as significant increases were seen with both $10^{-10}$ and $10^{-8} \mathrm{M}$, but not $10^{-12} \mathrm{M}$.

Diacylglycerol mass was measured $90 \mathrm{~s}$ after administration of either $10^{-8} \mathrm{M} 1,25(\mathrm{OH})_{2} \mathrm{D}_{3}$ or ethanol vehicle. Vehicle treated cells had a diacylglycerol content of $0.35 \pm 0.002 \mathrm{~mol} \%$ compared with $0.57 \pm 0.005 \mathrm{~mol} \%$ (mean $\pm \mathrm{SEM}, n=8)$ in the $1,25(\mathrm{OH})_{2} \mathrm{D}_{3}$-treated cells $(P<0.001)$.

Effect of $1,25(\mathrm{OH})_{2} D_{3}$ on colonic protein kinase $C$ activity. As shown in Fig. 3, administration of $10^{-8} \mathrm{M} 1,25(\mathrm{OH})_{2} \mathrm{D}_{3}$ 
Table I. Time Course of $1,25(\mathrm{OH})_{2} \mathrm{D}_{3}$ Effects on Cellular Phosphoinositides and Inositol Phosphates

\begin{tabular}{|c|c|c|c|c|c|c|}
\hline & \multicolumn{6}{|c|}{ Time } \\
\hline & 0 & $15 \mathrm{~s}$ & $30 \mathrm{~s}$ & $1 \min$ & $5 \min$ & $15 \min$ \\
\hline \multicolumn{7}{|c|}{ Phosphoinositide } \\
\hline PI & $75.7 \pm 0.8$ & $71.4 \pm 2.5$ & $67.5 \pm 2.7^{*}$ & $70.4 \pm 3.0$ & $80.0 \pm 3.0$ & $73.6 \pm 0.8$ \\
\hline PIP & $8.1 \pm 0.5$ & $7.7 \pm 0.3$ & $7.2 \pm 0.4$ & $7.5 \pm 0.2$ & $7.0 \pm 0.5$ & $7.7 \pm 0.1$ \\
\hline PIPP & $7.1 \pm 1.0$ & $4.9 \pm 0.4$ & $4.2 \pm 0.4^{\ddagger}$ & $4.5 \pm 0.3^{*}$ & $4.3 \pm 0.4^{*}$ & $5.6 \pm 0.2$ \\
\hline \multicolumn{7}{|c|}{ Inositol phosphates } \\
\hline IP & $2.8 \pm 2.0$ & $3.2 \pm 0.1$ & $4.9 \pm 0.4^{\S}$ & $4.2 \pm 0.1$ & $3.9 \pm 0.1$ & $3.0 \pm 0.1$ \\
\hline $\mathrm{IP}_{2}$ & $2.5 \pm 0.2$ & $3.2 \pm 0.1^{\S}$ & $3.0 \pm 0.2^{\S}$ & $4.5 \pm 0.2^{\S}$ & $2.3 \pm 0.1$ & $4.5 \pm 1.0$ \\
\hline $\mathrm{IP}_{3}$ & $1.8 \pm 0.1$ & $2.3 \pm 0.3$ & $4.2 \pm 0.1^{8}$ & $4.1 \pm 0.1^{\S}$ & $2.4 \pm 0.2$ & $3.0 \pm 0.2$ \\
\hline
\end{tabular}

Colonic epithelial preparations were prelabeled with $\left[{ }^{3} \mathrm{H}\right]$ myoinositol for $2 \mathrm{~h}$ at $37^{\circ} \mathrm{C}$. At $2 \mathrm{~h}, 0.21 \%$ of administered myoinositol was incorporated into cellular lipids (4.1 pmol myoinositol). After washing, the epithelial preparations were resuspended in buffer and exposed to $10^{-8} \mathrm{M}$ $1,25(\mathrm{OH})_{2} \mathrm{D}_{3}$ for $15 \mathrm{~s}-15 \mathrm{~min}$. The reactions were terminated by adding $0.67 \mathrm{ml}$ of $10 \% \mathrm{HClO}_{4}$, and after centrifugation the pellets were extracted with $0.5 \mathrm{ml}$ of $\mathrm{CHCl}_{3} / \mathrm{CH}_{3} \mathrm{OH} / 12 \mathrm{~N} \mathrm{HCl}$ 200:100:0.75 (vol/vol/vol). Individual phosphoinositides including PI, PIP, and PIPP were separated on $1 \% \mathrm{~K}$-oxalate impregnated silica gel $\mathrm{G}$ plates. The spots were visualized by spraying the plates with $\mathrm{En}^{3} \mathrm{hance}$ and exposing to Kodak X-ray film (SM-5) for 3-5 d. Individual phosphoinositide spots were scraped and counted. The supernatant was neutralized and the inositol phosphates, $\mathrm{IP}, \mathrm{IP}_{2}$, and $\mathrm{IP}_{3}$ were separated by anion exchange chromatography and assayed by scintillation counting. Data are presented as percentage of total disintegrations (phosphoinositides plus inositol phosphates, $\sim 100,000 \mathrm{dpm}$ /experiment) associated with each spot, and given as mean \pm SEM for six determinations from three separate experiments. ${ }^{*} P<0.05 ;{ }^{\ddagger} P<0.001 ;{ }^{\S} P<0.02$ vs. time 0 .

resulted in a rapid activation of colonic protein kinase C. At baseline, $75 \%$ of colonic protein kinase $C$ activity was in the cytosol, whereas only $25 \%$ was membrane-associated. Within $15 \mathrm{~s}$ after $1,25(\mathrm{OH})_{2} \mathrm{D}_{3}$ treatment, there was significant translocation of protein kinase $\mathrm{C}$ to the membrane fraction, and peak activation occurred with 1 min of exposure. Subsequently, there was a decrease in membrane-associated protein kinase $\mathrm{C}$ to the baseline level in spite of continued exposure to $1,25(\mathrm{OH})_{2} \mathrm{D}_{3}$. Total colonic protein kinase $\mathrm{C}$ activity (cytosol + membrane) did not change with $1,25(\mathrm{OH})_{2} \mathrm{D}_{3}$ treatment. Direct addition of $1,25(\mathrm{OH})_{2} \mathrm{D}_{3}$ to either membrane or cytosolic fractions had no effect on protein kinase $\mathrm{C}$ activity. Fig. 4 illustrates the concentration dependence of protein kinase $\mathrm{C}$ activation by $1,25(\mathrm{OH})_{2} \mathrm{D}_{3}$. All studies were performed with 1 min of $1,25(\mathrm{OH})_{2} \mathrm{D}_{3}$ treatment, and demonstrate a dose-re-

Table II. Concentration Dependence of $1,25(\mathrm{OH})_{2} \mathrm{D}_{3}$ Effects on Cellular Phosphoinositides and Inositol Phosphates

\begin{tabular}{lccc}
\hline & Vehicle & $10^{-10} \mathrm{M}$ & $10^{-8} \mathrm{M}$ \\
\hline Phosphoinositide & & & \\
$\quad$ PI & $76.2 \pm 0.8$ & $70.9 \pm 1.9^{*}$ & $69.0 \pm 1.7^{\ddagger}$ \\
PIP & $8.5 \pm 0.4$ & $8.7 \pm 0.3$ & $7.3 \pm 0.3$ \\
PIPP & $6.1 \pm 0.4$ & $5.5 \pm 0.3^{*}$ & $3.8 \pm 0.4^{\ddagger}$ \\
Inositol phosphate & & & \\
IP & $2.9 \pm 0.2$ & $4.0 \pm 0.2^{*}$ & $4.1 \pm 0.2^{*}$ \\
IP $_{2}$ & $2.8 \pm 0.1$ & $3.8 \pm 0.1^{\ddagger}$ & $4.2 \pm 0.2^{*}$ \\
$\mathrm{IP}_{3}$ & $1.8 \pm 0.3$ & $3.7 \pm 0.3^{\ddagger}$ & $5.0 \pm 0.3^{\ddagger 8}$ \\
& & & \\
\hline
\end{tabular}

Colonic epithelial preparations were prelabeled with $\left[{ }^{3} \mathrm{H}\right]$ myoinositol as described in Table $\mathrm{I}$, and treated with vehicle or $1,25(\mathrm{OH})_{2} \mathrm{D}_{3}$ $\left(10^{-8}\right.$ and $\left.10^{10} \mathrm{M}\right)$ for $30 \mathrm{~s}$. Membrane phosphoinositides were separated and quantitated as described in Table I. Data are presented as percent of total dpm associated with each spot and given as mean \pm SEM for six determinations in three separate experiments. ${ }^{*} P$ $<0.05 ;{ }^{\ddagger} P<0.01$ or less compared with vehicle. ${ }^{\S} P<0.02$ compared with $10^{-10} \mathrm{M}$. sponse relationship between $10^{-12}$ and $10^{-8} \mathrm{M} 1,25(\mathrm{OH})_{2} \mathrm{D}_{3}$. Exposure of colonic epithelium to the ethanol vehicle or to $25(\mathrm{OH}) \mathrm{D}_{3}$ at a concentration of up to $10^{-6} \mathrm{M}$ did not cause protein kinase $\mathrm{C}$ translocation to the membrane fraction. Similar $1,25(\mathrm{OH})_{2} \mathrm{D}_{3}$ induced activation of protein kinase $\mathrm{C}$ was seen using the isolated colonocyte preparation (data not shown).

Effect of $1,25(\mathrm{OH})_{2} \mathrm{D}_{3}$ on colonocyte $\left[\mathrm{Ca}^{+2}\right]_{i}$. Fig. 5 illustrates the effect of $10^{-8} \mathrm{M} 1,25(\mathrm{OH})_{2} \mathrm{D}_{3}$ on colonocyte $\left[\mathrm{Ca}^{+2}\right]_{i}$, determined using the flourescent dye fura- 2 . In buffer containing $1 \mathrm{mM} \mathrm{CaCl}_{2}$, the baseline $\left[\mathrm{Ca}^{+2}\right]_{\mathrm{i}}$ was $138 \pm 10 \mathrm{nM}$ (Fig. 5). The addition of $10^{-8} \mathrm{M} 1,25(\mathrm{OH})_{2} \mathrm{D}_{3}$ caused a rapid in-

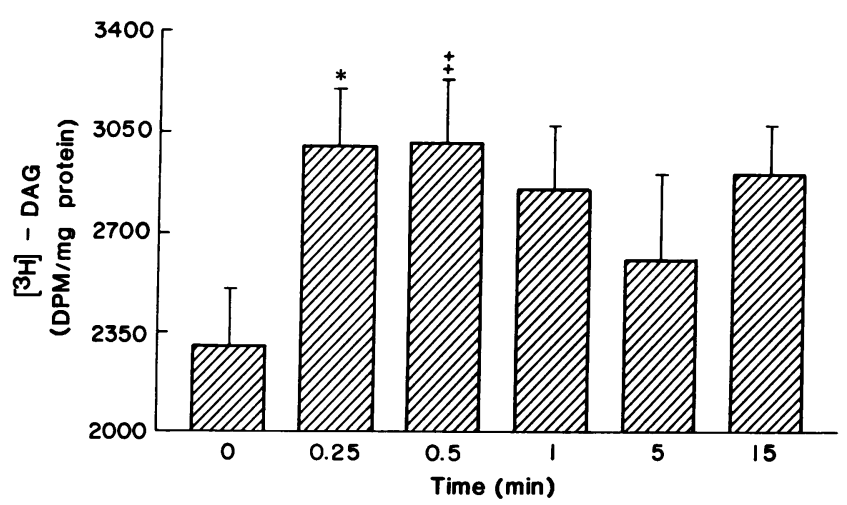

Figure 1. Time course of $1,25(\mathrm{OH})_{2} \mathrm{D}_{3}$-stimulated production of diacylglycerol $(D A G)$. Colonic epithelial preparations were prelabeled with $\left[{ }^{3} \mathrm{H}\right]$ arachidonate for $1 \mathrm{~h}$ at $37^{\circ} \mathrm{C}$. After washing, the epithelial preparations were resuspended in KRBG and exposed to $10^{-8} \mathrm{M}$ $1,25(\mathrm{OH})_{2} \mathrm{D}_{3}$ for $15 \mathrm{~s}-15 \mathrm{~min}$. After centrifugation, the pellets were extracted in chloroform/methanol (2:1, vol/vol), and the neutral lipid fraction separated using a silicic acid column. Diacylglycerol was separated by thin-layer chromatography, identified with iodine vapor, scraped from the plate, and counted. Data are presented as disintegrations per minute of DAG per milligram of protein and are given as mean \pm SEM for six determinations in four separate experiments. ${ }^{*} P<0.005 ;{ }^{\ddagger} P<0.001$ vs. baseline value. 


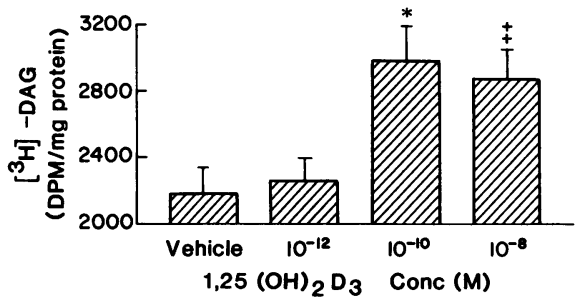

Figure 2. Concentration dependence of $1,25(\mathrm{OH})_{2} \mathrm{D}_{3}$-stimulated production of diacylglycerol $(D A G)$. Colonic epithelial preparations were prelabeled with $\left[{ }^{3} \mathrm{H}\right]$ arachidonate as described in Fig. 3, and treated with vehicle or $1,25(\mathrm{OH})_{2} \mathrm{D}_{3}\left(10^{-12}\right.$ to $\left.10^{-8} \mathrm{M}\right)$ for $30 \mathrm{~s}$ as reported in Table II. The amount of $\left[{ }^{3} \mathrm{H}\right] \mathrm{DAG}$ in the membrane pellet was determined as described in Fig. 3. Data are presented as mean \pm SEM for four to six determinations in three separate experiments. ${ }^{*} P$ $<0.005 ;{ }^{\ddagger} P<0.001$ vs. vehicle.

crease in $\left[\mathrm{Ca}^{+2}\right]_{\mathrm{i}}$ to $315 \pm 22 \mathrm{nM}$ after $20-30 \mathrm{~s}$ of treatment. This was followed by a decrease in $\left[\mathrm{Ca}^{+2}\right]_{i}$, and a subsequent second rise to a new plateau level. Using a lower concentration of $1,25(\mathrm{OH})_{2} \mathrm{D}_{3}, 10^{-10} \mathrm{M}$, the initial transient and plateau values of $\left[\mathrm{Ca}^{+2}\right]_{i}$ were $\sim 25 \%$ of that seen with $10^{-8} \mathrm{M}$. When colonocytes were studied in a calcium-free buffer containing 1 mM EGTA, the baseline $\left[\mathrm{Ca}^{+2}\right]_{\mathrm{i}}$ decreased to $65 \pm 10 \mathrm{nM}$. Addition of $10^{-8} \mathrm{M} 1,25(\mathrm{OH})_{2} \mathrm{D}_{3}$ resulted in a transient increase in $\left[\mathrm{Ca}^{+2}\right]_{\mathrm{i}}$ to $152 \pm 5 \mathrm{nM}$, but no secondary rise was observed and the plateau level was identical to the baseline value. When colonocytes were studied in a calcium-free without EGTA buffer, the baseline $\left[\mathrm{Ca}^{+2}\right]_{i}$ and response to $1,25(\mathrm{OH}) \mathrm{D}_{3}$ were intermediate between that seen with the $1 \mathrm{mM}$ calcium buffer

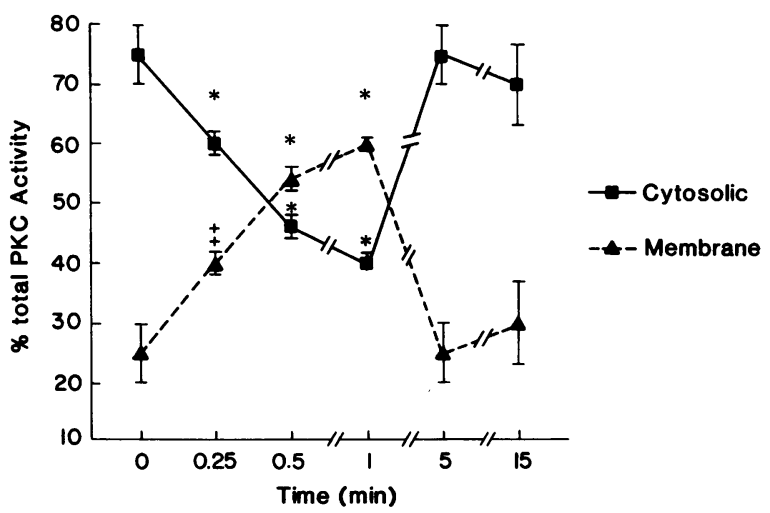

Figure 3. Time course of activation of protein kinase $\mathrm{C}(P K C)$ by $1,25(\mathrm{OH})_{2} \mathrm{D}_{3}$. Colonic epithelial preparations were incubated in $\mathrm{KRBG}$ at $37^{\circ} \mathrm{C}$ and treated with $10^{-8} \mathrm{M} 1,25(\mathrm{OH})_{2} \mathrm{D}_{3}$ for $15 \mathrm{~s}-15$ $\mathrm{min}$. After addition of $20 \mathrm{ml}$ of ice cold KRBG to each tube, the contents were centrifuged, and the pellets then homogenized in $5 \mathrm{ml}$ of buffer. After ultracentrifugation at $100,000 \mathrm{~g}$ for $60 \mathrm{~min}$, the supernatant $S_{1}$ (cytosolic fraction) was saved, and the pellet resuspended in homogenization buffer containing $0.3 \%$ Triton X 100 (wt/ wt) and left on ice for $60 \mathrm{~min}$. After centrifugation at $100,000 \mathrm{~g}$ for $60 \mathrm{~min}$, the supernatant $S_{2}$ (solubilized membrane fraction) was collected. Protein kinase $C$ in the $S_{1}$ and $S_{2}$ fractions was partially purified using DEAE-cellulose columns. Protein kinase $C$ activities in the $S_{1}$ and $S_{2}$ fractions were determined from the differences in phosphorylation of histone (type III-S) measured with and without addition of $80 \mu \mathrm{g} / \mathrm{ml}$ of phosphatidylserine. Data are expressed as percentage of total PKC activity in each fraction. Values given are mean \pm SEM for 21 determinations in seven separate experiments. ${ }^{*} P<0.001 ;{ }^{\ddagger} P<0.005$ vs. zero time value.

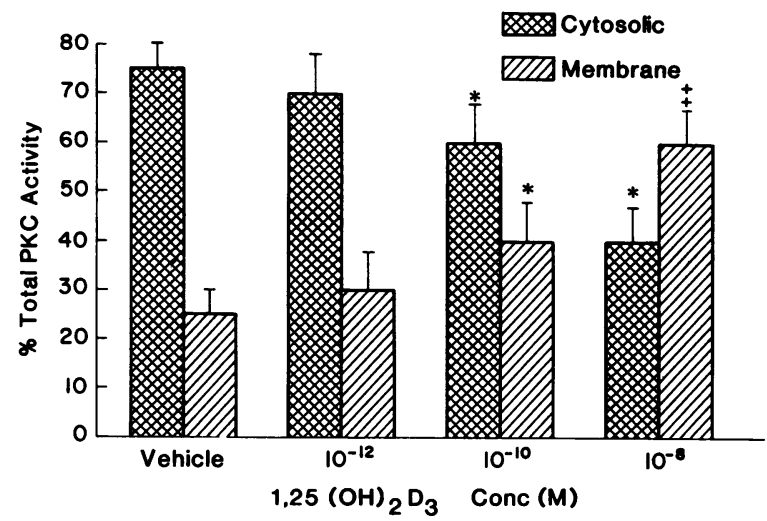

Figure 4. Concentration dependence of $1,25(\mathrm{OH})_{2} \mathrm{D}_{3}$-stimulated activation of protein kinase $\mathrm{C}(P K C)$. Colonic epithelial preparations were treated with $1,25(\mathrm{OH})_{2} \mathrm{D}_{3}\left(10^{-12}\right.$ to $\left.10^{-8} \mathrm{M}\right)$ or vehicle for 1 min. Cytosolic and solubilized membrane fractions were prepared; protein kinase $C$ was partially purified and assayed as described in Fig. 3. Data are expressed as percentage of total protein kinase $\mathrm{C}$ activity in each fraction, and are given as mean \pm SEM for nine determinations in three separate experiments. ${ }^{*} P<0.05$; ${ }^{\ddagger} P<.001$ vs. vehicle.

and the $1 \mathrm{mM}$ EGTA buffer. Addition of ethanol vehicle or $10^{-6} \mathrm{M} 25(\mathrm{OH}) \mathrm{D}_{3}$ had no effect on colonocyte $\left[\mathrm{Ca}^{+2}\right]_{\mathrm{i}}$ regardless of the buffer calcium concentration used.

Effect of $1,25(\mathrm{OH})_{2} \mathrm{D}_{3}$ on $\left[{ }^{3} \mathrm{H}\right]$ thymidine incorporation in rat colonocytes. $\left[{ }^{3} \mathrm{H}\right]$ Thymidine incorporation was measured four hours after a single dose of $1,25(\mathrm{OH})_{2} \mathrm{D}_{3}$. Vitamin $\mathrm{D}$ treated animals incorporated $44 \%$ more $\left[{ }^{3} \mathrm{H}\right]$ thymidine/mgDNA than vehicle-treated animals $(33.5 \pm 4.3$ vs. $48.4 \pm 5.8$ pmol of $\left[{ }^{3} \mathrm{H}\right]$ thymidine/mg of DNA, mean \pm SEM, $n=4, P$ $<0.05$ ).

\section{Discussion}

The experiments described in this paper are the first to demonstrate an effect of $1,25(\mathrm{OH})_{2} \mathrm{D}_{3}$ on phosphatidylinositol me-

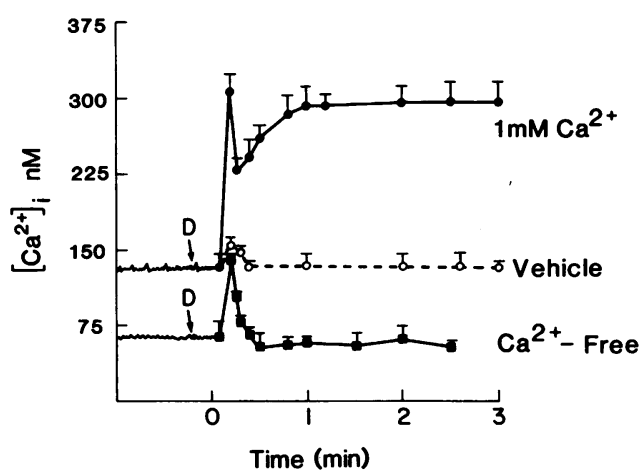

Figure 5. Effect of $10^{-8} \mathrm{M} 1,25(\mathrm{OH})_{2} \mathrm{D}_{3}$ on $\left[\mathrm{Ca}^{+2}\right]_{\mathrm{i}}$. Isolated colonocytes were incubated with $1 \mu \mathrm{M}$ fura-2AM for $30 \mathrm{~min}$ at $37^{\circ} \mathrm{C}$. After washing, the cells were suspended in buffer containing either $1 \mathrm{mM}$ $\mathrm{CaCl}_{2}(\bullet, 0)$ or $1 \mathrm{mM} \mathrm{K}_{2} \mathrm{H}_{2}$ EGTA ( $(\bullet)$. The kinetics of fluorescence changes were measured at excitation wavelengths of 340 and 380 $\mathrm{nM}$, with emission at $510 \mathrm{nM}$. $\left[\mathrm{Ca}^{+2}\right]_{\mathrm{i}}$ was calculated based on the formula of Grynkyewicz et al. (32). At the times indicated by the arrows, $10^{-8} \mathrm{M} 1,25(\mathrm{OH})_{2} \mathrm{D}_{3}(\bullet, \varpi)$ or ethanol vehicle (o) was injected directly into the cuvette. Data presented are the mean \pm SD of two to five determinations in three separate experiments. 
tabolism, with subsequent activation of protein kinase $\mathrm{C}$ and regulation of $\left[\mathrm{Ca}^{+2}\right]_{\mathrm{i}}$ in intestinal tissue. The responses to $1,25(\mathrm{OH})_{2} \mathrm{D}_{3}$ occur rapidly, within seconds to minutes, suggesting that they are not the result of the classic steroidlike or genomic action of $1,25(\mathrm{OH})_{2} \mathrm{D}_{3}(36)$. This mode of action is much slower, inasmuch as $1,25(\mathrm{OH})_{2} \mathrm{D}_{3}$ interacts with its receptor forming a complex which binds to chromatin and alters gene transcription and eventually protein synthesis $(36,37)$.

Little information is available on the effect of $1,25(\mathrm{OH})_{2} \mathrm{D}_{3}$ on membrane PI turnover in various target cells. In a preliminary report, MacLaughlin et al. (38) showed that exposure of keratinocytes to $1,25(\mathrm{OH})_{2} \mathrm{D}_{3}$ resulted in a two- to fivefold elevation in the level of $\mathrm{IP}_{3}$ within $30 \mathrm{~s}$ and an increase in metabolism of PI to PIPP, the metabolite that is the source of $I_{P_{3}}$. In contrast, Chisholm et al. (39) found no effect of $1,25(\mathrm{OH})_{2} \mathrm{D}_{3}$ on the level of $\mathrm{IP}_{3}$ in $\mathrm{GH}_{4} \mathrm{C}_{1}$ pituitary cells. Baran and Kelly (40) have reported that $1,25(\mathrm{OH})_{2} \mathrm{D}_{3}$ stimulates phospholipase $\mathrm{A}_{2}$-induced deacylation of phosphatidylinositol in hepatocyte membranes, generating lysophosphatidylinositol which can increase hepatocyte cytosolic calcium levels. In our studies, $1,25(\mathrm{OH})_{2} \mathrm{D}_{3}$ caused a rapid decrease in the colonic levels of membrane phosphoinositides, and an increase in the cellular content of inositol phosphates, most prominently $\mathrm{IP}_{3}$. The increase in colonocyte $\mathrm{IP}_{3}$ began at $15 \mathrm{~s}$ and was significant by $30 \mathrm{~s}$. The rise in $\mathrm{IP}_{3}$ coincided with the initial rise in $\left[\mathrm{Ca}^{+2}\right]_{\mathrm{i}}$ suggesting that it may be responsible for the calcium response observed in these cells. This is consistent with the known stimulatory effect of $\mathrm{IP}_{3}$ on the release of calcium from an endoplasmic reticulum storage pool (41). Activation of the phosphoinositol pathway has also been shown to increase transmembrane calcium cycling by acting upon membrane calcium channels, although the mechanisms for this effect remain uncertain (42).

Our studies have also demonstrated that $1,25(\mathrm{OH})_{2} \mathrm{D}_{3}$ stimulates diacylglycerol formation. The origin of this diacylglycerol is not entirely clear, however, two observations would tend to support phosphoinositol as the major precursor for diacylglycerol in this study. First, the time course of diacylglycerol formation coincides with the time course of phosphoinositide breakdown. Secondly, phosphoinositides are the major phospholipids labeled when colonic epithelium is exposed to $\left[{ }^{3} \mathrm{H}\right]$ arachidonate. This does not, however, exclude the possibility that some of the diacylglycerol formed may have come from other sources such as phosphatidylcholine.

Activation of protein kinase $\mathrm{C}$, as indicated by translocation of the enzyme from the cytosol to the membrane fraction (43), temporally coincides with diacylglycerol formation and the increase in $[\mathrm{Ca}]_{\mathrm{i}}$. As has been described in other systems (43), the translocation of protein kinase $C$ to the membrane appears to be transient in spite of continued exposure to $1,25(\mathrm{OH})_{2} \mathrm{D}_{3}$. This may reflect modification or degradation of the protein kinase $\mathrm{C}$ to a form that has altered requirements for diacylglycerol, phosphatidylserine, or calcium, and which may have additional intracellular actions (44). Since protein kinase $\mathrm{C}$ appears to play an important role in cell proliferation and differentiation $(45,46), 1,25(\mathrm{OH})_{2} \mathrm{D}_{3}$-induced activation of protein kinase $C$ is a potential mechanism by which the secosteroid affects colonocyte growth and maturation. Bile salts and dietary fatty acids, agents which alter colonocyte proliferation and have been implicated in the promotion of colonic carcinoma, have been demonstrated to also activate colonocyte protein kinase $\mathrm{C}(16-18)$. The finding that $1,25(\mathrm{OH})_{2} \mathrm{D}_{3}$ stimulates colonocyte $\left[{ }^{3} \mathrm{H}\right]$ thymidine uptake is consistent with the proliferative effect of protein kinase $C$ as well as the known proliferative effect of vitamin D on intestinal mucosa (6).

Previous studies of the effect of $1,25(\mathrm{OH})_{2} \mathrm{D}_{3}$ on protein kinase $\mathrm{C}$ activity in other cell types have found conflicting results. Ways et al. (47) reported that $1,25(\mathrm{OH})_{2} \mathrm{D}_{3}$ enhanced phorbol ester-stimulated differentiation and protein kinase Cdependent phosphorylation of cellular proteins in the U937 human monoblastoid cell. $1,25(\mathrm{OH})_{2} \mathrm{D}_{3}$ increased the protein kinase $\mathrm{C}$ level in both the cytosolic and membrane fractions. Martell et al. (48) reported that $1,25(\mathrm{OH})_{2} \mathrm{D}_{3}$-induced differentiation of HL- 60 cells was inhibited by exposure of the cells to a protein kinase $\mathrm{C}$ inhibitor $\mathrm{H}-7$. They demonstrated that protein kinase $\mathrm{C}$ activity was increased twofold after $24 \mathrm{~h}$ of exposure to $1,25(\mathrm{OH})_{2} \mathrm{D}_{3}$, and that this response could be blocked by the protein synthesis inhibitor cycloheximide. In contrast, Mezzetti et al. (49) reported that $1,25(\mathrm{OH})_{2} \mathrm{D}_{3}$ induced differentiation of $\mathrm{U} 937$ cells without protein kinase $\mathrm{C}$ activation, whereas phorbol ester-induced differentiation of these cells was mediated through protein kinase C. Sasaki et al. (50) observed that $1,25(\mathrm{OH})_{2} \mathrm{D}_{3}$ decreased the cell growth and enhanced chemical transformation of BALB 3T3 cells without activation of protein kinase $C$. It appears, therefore, that although $1,25(\mathrm{OH})_{2} \mathrm{D}_{3}$ stimulates protein kinase $\mathrm{C}$ in colonocytes and other cell types, the effects of this secosteroid on cell growth and differentiation are complex and involve other mechanisms in addition to protein kinase $\mathrm{C}$ activation.

We have demonstrated that $1,25(\mathrm{OH})_{2} \mathrm{D}_{3}$ results in a rapid rise in colonocyte $\left[\mathrm{Ca}^{+2}\right]_{i}$. The specificity of this response is supported by the observation that exposure of colonocytes to a 100 -fold higher concentration of $25(\mathrm{OH})$ vitamin $\mathrm{D}_{3}$ did not alter $\left[\mathrm{Ca}^{+2}\right]_{\mathrm{i}}$. When the colonocytes were studied in a calciumfree buffer with or without $1 \mathrm{mM}$ EGTA, $1,25(\mathrm{OH})_{2} \mathrm{D}_{3}$ caused an increase in $\left[\mathrm{Ca}^{+2}\right]_{i}$ but less than that seen in calcium containing buffers. These results indicate that $1,25(\mathrm{OH})_{2} \mathrm{D}_{3}$ is either stimulating calcium influx or is causing release of calcium from a cellular pool that is readily exchangeable with extracellular calcium. Since an increase in $\left[\mathrm{Ca}^{+2}\right]_{i}$ was seen in calcium-free EGTA containing buffer, $1,25(\mathrm{OH})_{2} \mathrm{D}_{3}$ must release calcium from intracellular storage sites. The relationship of the phosphoinositol signal transduction pathway to changes in $\left[\mathrm{Ca}^{+2}\right]_{\mathrm{i}}$ has been extensively studied. Most studies indicate that $\mathrm{IP}_{3}$ stimulates release of calcium from endoplasmic reticulum (51), although others suggest that $I_{P_{3}}$ has effects at the plasma membrane (41). Further work to define the relationship between colonocyte phosphoinositol metabolism and changes in $\left[\mathrm{Ca}^{+2}\right]_{\mathrm{i}}$ is needed.

A number of previous studies in diverse cell types have also documented an effect of $1,25(\mathrm{OH})_{2} \mathrm{D}_{3}$ on $\left[\mathrm{Ca}^{+2}\right]_{i}(38,39$, 52-54). Baran and Milne (52) demonstrated a dose-dependent effect of $1,25(\mathrm{OH})_{2} \mathrm{D}_{3}$ on hepatocyte $\left[\mathrm{Ca}^{+2}\right]_{i}$ that occurred both in the presence and absence of extracellular calcium, indicating that $1,25(\mathrm{OH})_{2} \mathrm{D}_{3}$ mobilized intracellular calcium pools. Sugimoto et al. (53) demonstrated that as little as $10^{-10} \mathrm{M}$ $1,25(\mathrm{OH})_{2} \mathrm{D}_{3}$ increased $\left[\mathrm{Ca}^{+2}\right]_{\mathrm{i}}$ in bovine parathyroid cells, whereas $25(\mathrm{OH}) \mathrm{D}_{3}$ and $24,25(\mathrm{OH})_{2} \mathrm{D}_{3}$ were ineffective. The calcium channel inhibitors verapamil and diltiazem did not block the response to $1,25(\mathrm{OH})_{2} \mathrm{D}_{3}$. Leiberherr (54) showed that $1,25(\mathrm{OH})_{2} \mathrm{D}_{3}$, in a concentration as low as $10^{-11} \mathrm{M}$, transiently increased $\left[\mathrm{Ca}^{+2}\right]_{\mathrm{i}}$ in mouse osteoblasts within the $1 \mathrm{st}$ min of exposure (54). Studies using calcium-free buffers and inhibitors of calcium release from various cellular compartments suggested that the major effect of $1,25(\mathrm{OH})_{2} \mathrm{D}_{3}$ was to 
enhance calcium influx, although $1,25(\mathrm{OH})_{2} \mathrm{D}_{3}$ also appeared to release calcium from an endoplasmic reticulum pool and to accelerate calcium efflux. In a preliminary report, MacLaughlin et al. (38) found that $10^{-8} \mathrm{M} 1,25(\mathrm{OH})_{2} \mathrm{D}_{3}$ increased $\left[\mathrm{Ca}^{+2}\right]_{\mathrm{i}}$ twofold in keratinocytes, whereas no response was seen with $25(\mathrm{OH}) \mathrm{D}_{3}$ or vitamin $\mathrm{D}_{3}(38)$. In their studies, $1,25(\mathrm{OH})_{2} \mathrm{D}_{3}$ provoked an increase in $\left[\mathrm{Ca}^{+2}\right]_{\mathrm{i}}$ even in a calcium-free buffer. Thus, $1,25(\mathrm{OH})_{2} \mathrm{D}_{3}$ appears to alter the $\left[\mathrm{Ca}^{+2}\right]_{i}$ level in different cell types by several mechanisms, including alterations in membrane calcium influx and efflux, release of various intracellular calcium stores, and by potentiating responsiveness to other agents that operate through cytosolic calcium. In colonocytes and most other cells, the response to $1,25(\mathrm{OH})_{2} \mathrm{D}_{3}$ is very rapid, consistent with a direct action on cell membranes.

The mechanism by which $1,25(\mathrm{OH})_{2} \mathrm{D}_{3}$ stimulates membrane phosphoinositide turnover remain to be elucidated. Previous studies have not identified a plasma membrane vitamin $\mathrm{D}$ receptor, thus further research is needed to assess the membrane association of $1,25(\mathrm{OH})_{2} \mathrm{D}_{3}$, the role of GTP-binding proteins, and activation of phospholipase $\mathrm{C}$ in response to $1,25(\mathrm{OH})_{2} \mathrm{D}_{3}$.

The possible relationship among the rapid increase in $\left[\mathrm{Ca}^{+2}\right]_{i}$, protein kinase $\mathrm{C}$ activation, and the regulation of transcellular calcium transport also deserves further study. Previous studies have demonstrated enhancement of calcium uptake into intestinal and skeletal muscle cells within 2-5 min of $1,25(\mathrm{OH})_{2} \mathrm{D}_{3}$ exposure (55-57), a time period consistent with the rapid effects observed in the present paper. It is possible that $1,25(\mathrm{OH})_{2} \mathrm{D}_{3}$-induced PI breakdown initiates a series of membrane events that increase and ultimately sustain calcium transport, i.e., a "liponomic" mode of action (13). In hepatocytes, $1,25(\mathrm{OH})_{2} \mathrm{D}_{3}$ increases hepatocyte phospholipase $A_{2}$ activity after $2.5 \mathrm{~min}$ of exposure (40), and in renal and intestinal cells, membrane phospholipid composition is altered within 30 min $(13,14)$. Rasmussen et al. (13) demonstrated that the early effects of $1,25(\mathrm{OH})_{2} \mathrm{D}_{3}$ on intestinal brush border membrane lipid composition and calcium uptake were not blocked by inhibitors of transcription and translation, indicating a direct membrane effect. Putkey et al. (58) examined the effect of vitamin D deficiency and essential fatty acid deficiency on enterocyte membrane fluidity lipid composition and calcium flux. Of interest was their finding that the ileum from essential fatty acid and vitamin D deficient chicks failed to respond to vitamin $\mathrm{D}$ with an increase in calcium flux. Analysis of lipid composition revealed that these deficient chicks had increased amounts of saturated fatty acids and decreased amounts of linoleic acid. Brasitus et al. (15) showed that $1,25(\mathrm{OH})_{2} \mathrm{D}_{3}$ treatment increased the dynamic component of fluidity and corrected the fatty acid composition of small intestinal brush border membranes from vitamin D-deprived rats. These changes occurred within 1-2 $\mathrm{h}$ of treatment, temporally preceding changes in duodenal calcium absorption.

Further work must be directed toward identifying specific cellular proteins that are phosphorylated after $1,25(\mathrm{OH})_{2} \mathrm{D}_{3}$ induced protein kinase $\mathrm{C}$ activation, and to the elucidation of the functional significance of these target proteins in calcium transport and cell growth and differentiation.

\section{Acknowledgments}

The authors acknowledge the expert secretarial assistance of Kathy Cobb and Lynn Nelson.

This research was supported in part by the following grants:
CA-36745, 5 P30 DK-26678 (Clinical Nutrition Research Unit), and DK-39573 from the U.S. Public Health Service and The Goldblatt Cancer Research Foundation. Thomas A. Brasitus is the recipient of a MERIT Award from the National Cancer Institute.

\section{References}

1. Norman, A. W., J. Roth, and L. Orci. 1982. The vitamin D endocrine system: steroid metabolism, hormone receptors, and biological response (calcium binding proteins). Endocr. Rev. 3:331-366.

2. Niendorf, A., H. Arps, and M. Dietel. 1987. Effect of 1,25-dihydroxyvitamin $\mathrm{D}_{3}$ on human cancer cells in vitro. J. Steroid Biochem. 27:825-828.

3. Koeffler, H. P. 1985. Vitamin D: myeloid differentiation and proliferation. Haematol. Blood Transfus. 29:409-417.

4. Brehier, A., and M. Thomasset. 1988. Human colon cell line HT-29: characterization of 1,25-dihydroxyvitamin $D_{3}$ receptor and induction of differentiation by the hormone. J. Steroid Biochem. 29:265-270.

5. Wargovich, M. J., and P. H. Lointier. 1987. Calcium and vitamin D modulate mouse colon epithelial proliferation and growth characteristics of a human colon tumor cell line. Can. J. Physiol. Pharmacol. 65:472-477.

6. Birge, S. J., and D. H. Alpers. 1973. Stimulation of intestinal mucosal proliferation by vitamin D. Gastroenterology. 64:977-982.

7. Hylander, E., K. Ladefauged, and S. Jarnum. 1980. The importance of the colon in calcium absorption following small intestinal resection. Scand. J. Gastroenterol. 15:55-60.

8. Grinstead, N. C., C. Y. C. Pak, and G. Krejs. 1984. Effect of 1,25-dihydroxyvitamin $\mathrm{D}_{3}$ on calcium absorption in the colon of healthy humans. Am. J. Physiol. 247:G189-192.

9. Garland, C. F., and F. C. Garland. 1980. Do sunlight and vitamin D reduce the likelihood of colon cancer? Int. J. Epidemiol. 9:227-231.

10. Garland, C., E. Barrett-Connor, A. H. Rossott, R. B. Shekelle, M. H. Criqui, and O. Paul. 1985. Dietary vitamin D and calcium and risk of colorectal cancer: a 19-year prospective study in men. Lancet. i:307-309.

11. Minghetti, P. P., and A. W. Norman. 1988. 1,25(OH) $)_{2}$-vitamin $\mathrm{D}_{3}$ receptors: gene regulation and genetic circuiting. FASEB (Fed. Am. Soc. Exp. Biol.) J. 2:3043-3053.

12. Ben Nasr, L., J.-D. Monet, and P. A. Lucas. 1988. Rapid (10-minute) stimulation of rat duodenal alkaline phosphatase activity by 1,25-dihydroxyvitamin $\mathrm{D}_{3}$. Endocrinology. 123:1778-1782.

13. Rasmussen, H., T. Matsumoto, O. Fontaine, and D. B. P. Goodman. 1982. Role of changes in membrane lipid structure in the action of 1,25-dihydroxyvitamin $\mathrm{D}_{3}$. Fed. Proc. 41:72-77.

14. Kurnik, B. R. C., M. Huskey, D. Hagerty, and K. A. Hruska. 1986. Vitamin D metabolites stimulate phosphatidylcholine transfer to renal brush-border membranes. Biochim. Biophys. Acta. 858:47-55.

15. Brasitus, T. A., P. K. Dudeja, B. Eby, and K. Lau. 1986. Correction by 1,25-dihydroxycholecalciferol of the abnormal fluidity and lipid composition of enterocyte brush border membranes in vitamin D deprived rats. J. Biol. Chem. 261:16404-16409.

16. Craven, P. A., J. Pfanstiel, and F. R. DeRubertis. 1987. Role of activation of protein kinase $C$ in the stimulation of colonic epithelial proliferation and reactive oxygen formation by bile acids. J. Clin. Invest. 79:532-541.

17. Craven, P. A., and F. R. DeRubertis. 1988. Role of activation of protein kinase $C$ in the stimulation of colonic epithelial proliferation by unsaturated fatty acids. Gastroenterology. 95:676-685.

18. Craven, P. A., J. Pfanstiel, and F. R. DeRubertis. 1986. Role of reactive oxygen in bile salt stimulation of colonic epithelial proliferation. J. Clin. Invest. 77:850-859.

19. Roediger, W. E. W. 1982. Utilization of nutrients by isolated epithelial cells of the rat colon. Gastroenterology. 83:424-429.

20. Kraft, A. S., W. B. Anderson, H. C. Cooper, and J. J. Sando. 1982. Decrease in cytosolic calcium/phospholipid dependent protein 
kinase activity following phorbol ester treatment of EL4 thymoma cells. J. Biol. Chem. 257:13193-13196.

21. Snyder, F. 1976. Chromatographic analysis of alkyl and alk-1enyl ether lipids and their derivates. In Lipid Chromatographic Analysis. Volume 1. G. V. Marinetti, editor. Marcel Dekker, Inc., New York. 116-148.

22. Folch, J., M. Lees, and G. H. Sloane-Stanley. 1957. A simple method for the isolation and purification of the total lipids from the animal tissues. J. Biol. Chem. 227:497-509.

23. Bartlett, G. R. 1959. Phosphorus assay in column chromatography. J. Biol. Chem. 234:466-468.

24. Preiss, J., C. R. Loomis, R. W. Bishop, R. Stein, J. E. Niedel, and R. M. Bell. 1986. Quantitative measurement of Sn-1,2-diacylglycerols present in platelets, hepatocytes, and ras- and sis transformed normal rat kidney cells. J. Biol. Chem. 261:8597-8600.

25. MacDonald, M. L., K. F. Mack, C. N. Richardson, and J. A. Glomset. 1988. Regulation of diacylglycerol kinase reaction in Swiss 3T3 cells. J. Biol. Chem. 263:1575-1583.

26. Wright, T. M., L. A. Rangan, H. S. Shin, and D. M. Raben. 1988. Kinetic analysis of 1,2-diacylglycerol mass levels in cultured fibroblasts. J. Biol. Chem. 263:9374-9380.

27. Muldoon, L. L., K. D. Rodland, M. L. Forsythe, and B. E. Magun. 1989. Stimulation of phosphatidylinositol hydrolysis, diacylglycerol release and gene expression in response to endothelin, a potent new agonist for fibroblast and smooth muscle cells. J. Biol. Chem. 264:8529-8536.

28. Downes, C. P., M. C. Mussat, and R. H. Michell. 1982. The inositol trisphosphate phosphomonoesterase of the human erythrocyte membrane. Biochem. J. 203:169-177.

29. VanDongen, C. J., H. Zwiers, and W. H. Gispen. 1985. Microdetermination of phosphoinositides in a single extract. Anal. Biochem. 144:104-109.

30. Brasitus, T. A. 1983. Lipid dynamics and protein-lipid interactions in rat colonic epithelial cell basolateral membrane. Biochim. Biophys. Acta. 732:20-30.

31. Sage, S. O., and T. J. Rink. 1987. The kinetics of changes in intracellular calcium concentration in Fura-2-loaded human platelets. J. Biol. Chem. 262:16364-16369.

32. Grynkiewicz, G., M. Poenie, and R. Y. Tsien. 1985. A new generation of $\mathrm{Ca}^{+2}$ indicators with greatly improved fluorescence properties. J. Biol. Chem. 260:3440-3450.

33. Verbin, R. S., and E. Farber. 1967. Effect of cycloheximide on the cell cycle of the crypts of the small intestine of the rat. J. Cell Biol. 35:649-658.

34. Burton, K. 1956. A study of the conditions and mechanism of the diphenylamine reaction for the colorimetric estimation of deoxyribonucleic acid. Biochem. J. 62:315-322.

35. Snedcor, G. W., and G. W. Cochran. 1976. Samplng from a normally distributed population. In Statistical Methods. Iowa State University Press, Ames, IA. 32-66.

36. Norman, A. W., and F. P. Ross. 1979. Vitamin D seco-steroids: unique molecules with both hormone and possible membranophilic properties. Life Sci. 24:759-770.

37. Eisman, J. A., J.-C. Fragonas, and U. L. McMenemy. 1988. Rapid turnover of the 1,25-dihydroxyvitamin $\mathrm{D}_{3}$ receptor in human target cells. Endocrinology. 122:1613-1621.

38. MacLaughlin, J. A., L. C. Cantley, S. A. Chahwala, and M. F. Holick. 1987. 1,25-(OH $)_{2}-D_{3}$ increases intracellular calcium in human keratinocytes by stimulating phosphatidylinositol turnover. J. Bone Miner. Res. 2(Suppl. 1):76. (Abstr.)

39. Chisholm, J. C., S. Kim, and A. H. Tashjian. 1988. Modulation by 1,25-dihydroxycholecalciferol of the acute change in cytosolic free calcium induced by thyrotropin-releasing hormone in $\mathrm{GH}_{4} \mathrm{C}_{1}$ pituitary cells. J. Clin. Invest. 81:661-668.

40. Baran, D. T., and A. M. Kelly. 1988. Lysophosphatidylinositol: a potential mediator of 1,25-dihydroxyvitamin D-induced increments in hepatocyte cytosolic calcium. Endocrinology. 122:930-934.
41. Alkon, D. L., and H. Rasmussen. 1988. A spacial-temporal model of cell activation. Science (Wash. DC). 239:998-1005.

42. Kuno, M., and P. Gardnes. 1987. Ion channels activated by inositol 1,4,5-trisphosphate in plasma membrane of human T-lymphocyte. Nature (Lond.). 326:301-304.

43. Kikkawa, U., and Y. Nishizuka. 1986. The role of protein kinase C in transmembrane signaling. Annu. Rev. Cell Biol. 2:149178.

44. Melloni, E., S. Pontremoli, M. Michetti, O. Sacco, B. Sparatore, and B. L. Horecker. 1986. The involvement of calpain in the activation of protein kinase $\mathrm{C}$ in neutrophils stimulated by phorbol myristic acid. J. Biol. Chem. 261:4101-4108.

45. Nishizuka, Y. 1984. The role of protein kinase $C$ in cell surface signal transduction and tumor production. Nature (Lond.). 308:693698.

46. Weinstein, B. 1988. The origins of human cancer: molecular mechanisms of carcinogenesis and their implications for cancer prevention and treatment-twenty-seventh G. H. A. Clowes Memorial Award Lecture. Cancer Res. 48:4135-4143.

47. Ways, D. K., R. C. Dodd, T. E. Bennett, T. K. Gray, and H. S. Earp. 1987. 1,25-dihydroxyvitamin $D_{3}$ enhances phorbol ester-stimulated differentiation and protein kinase C-dependent substrate phosphorylation activity in the U937 human monoblastoid cell. Endocrinology. 121:1654-1660.

48. Martell, R. E., R. U. Simpson, and J. M. Taylor. 1987. 1,25-dihydroxyvitamin $\mathrm{D}_{3}\left(1,25-(\mathrm{OH})_{2} \mathrm{D}_{3}\right)$ acts through protein kinase $\mathrm{C}$ to induce HL-60 cell differentiation. Fed. Proc. 46:603. (Abstr.)

49. Mezzetti, O., G. P. Bagnara, M. C. Monti, L. P. Casolo, L. Bonsi, and M. A. Brunelli. 1987. Phorbol esters, but not the hormonal form of vitamin $D$, induce changes in protein kinase $C$ during differentiation of human histiocytic lymphoma cell line (U-937). Life Sci. 40:2111-2117.

50. Sasaki, K., K. Chida, H. Hashiba, N. Kamata, E. Abe, T. Suda, and T. Kuroki. 1986. Enhancement by 1 alpha, 25-dihydroxyvitamin $\mathrm{D}_{3}$ of chemically induced transformation of BALB 3T3 cells without induction of ornithine decarboxylase or activation of protein kinase $C$. Cancer Res. 46:604-610.

51. Berridge, M. J., and R. F. Irvine. 1984. Inositol trisphosphate, a novel second messenger in cellular signal transduction. Nature (Lond.). 312:315-321.

52. Baran, D. T., and M. L. Milne. 1986. 1,25dihydroxyvitamin D increases hepatocyte cytosolic calcium levels. J. Clin. Invest. 77:16221626.

53. Sugimoto, T., C. Ritter, I. Ried, J. Morrissey, and E. Slatopolsky. 1988. Effect of 1,25-dihydroxyvitamin $\mathrm{D}_{3}$ on cytosolic calcium in dispersed parathyroid cell. Kidney Int. 33:850-854.

54. Lieberherr, M. 1987. Effects of vitamin $D_{3}$ metabolites on cytosolic free calcium in confluent mouse osteoblasts. J. Biol. Chem. 262:13168-13173

55. Yoshumoto, Y., I. Nemere, and A. W. Norman. 1986. Hypercalcemia inhibits the rapid stimulatory effect on calcium transport in perfused duodena from normal chicks mediated in vitro by 1,25-dihydroxyvitamin $\mathrm{D}_{3}$. Endocrinology. 118:2300-2304.

56. DeBoland, A. R., and R. L. Boland. 1987. Rapid changes in skeletal muscle calcium uptake induced in vitro by 1,25 -dihydroxyvitamin $\mathrm{D}_{3}$ are suppressed by calcium channel blockers. Endocrinology. 120:1858-1864.

57. Nemere, I., and C. M. Szego. 1981. Early actions of parathyroid hormone and 1,25-dihydroxycholecalciferol on isolated epithelial cells from rat intestinel. I. Limited lysosomal enzyme release and calcium uptake. Endocrinology. 108:1450-1462.

58. Putkey, J. A., A. M. Spielvogel, R. D. Sauerheber, C. S. Dunlap, and A. W. Norman. 1982. Vitamin D-mediated intestinal calcium transport. Effects of essential fatty acid deficiency and spin label studies of enterocyte membrane lipid fluidity. Biochim. Biophys. Acta. 588:177-190. 